\title{
The Impact of Malaysian Code on Corporate Governance and Political Connections on Accounting Conservatism
}

\author{
Yuyun A. Sejati \\ University of Wisconsin Oshkosh \\ Christopher R. Jones \\ University of Wisconsin Oshkosh
}

This study explores the relationships between accounting conservatism, the integration of the Malaysian Code on Corporate Governance (MCCG) into Bursa Malaysia listing requirements in 2001, and firms' political connections. We find evidence that MCCG results in improved accounting conservatism in Malaysia. Furthermore, we find that prior to MCCG, firms with political connections lack accounting conservatism, and firms without political connections demonstrate accounting conservatism. After MCCG is included in Bursa Malaysia listing rules, both firms with and without political connections show improved accounting conservatism. More interestingly, politically-connected firms demonstrate stronger accounting conservatism compared to non-connected firms after the MCCG.

\section{INTRODUCTION}

The objective of this study is to explore the relationship between accounting conservatism, corporate governance reform, and firms' political connections in Malaysia. Specifically, we examine whether the integration of Malaysian Code on Corporate Governance (MCCG) into Bursa Malaysia listing rules in 2001 affects accounting conservatism, and whether the existence of firms' political connections affects the association between the corporate governance reform and accounting conservatism.

Accounting conservatism often is considered one of the desired properties of reported income. Accounting conservatism, defined as the asymmetric verifiability required in recognizing profit versus losses, plays a significant role in investor protection and corporate governance by constraining management's opportunistic financial reporting behavior (Watts, 2003a). Research evidence on accounting conservatism suggests asymmetric verifiability is crucial to reduce manipulation and fraud (Watts, 2003b). In addition, the persistent influence of conservatism on accounting practice suggests that it confers benefits to economic agents who use, prepare, or regulate financial reports (Bushman \& Piotroski, 2006). Knowledge of the nature and determinants of accounting conservatism is fundamental to understanding how and why financial reports are used in contracting, valuation, legal, and other institutional settings (Guay \& Verrechia, 2006).

A salient institutional feature of East Asian economies, including Malaysia, is the existence of a widespread culture of cronyism, in which many companies develop close connections with the government or politicians in order to obtain benefits such as preferential access to markets, tax discounts, 
easier access to credits, government subsidies, and so on. Bushman, Piotroski, and Smith (2004) assert that one aspect of political involvement that can affect financial transparency is politicians' abuse of their controls over banks and regulatory policy to favor their cronies in return for bribes, political supports, nepotism, and so on. Ball, Robin, and Wu (2003) suggest that political connection may have contributed to the low level of financial reporting quality in some East Asian countries. Malaysia, in particular, has a well-documented history of politically-connected firms, which has been used in many prior studies in the areas of financial reporting, corporate governance, and corporate finance (e.g., Bliss, Gul, \& Majid, 2011; Bliss \& Gul, 2012a, 2012b; Faccio, 2006; 2007; Fung, Gul, \& Radhakrishnan, 2015; Gomez \& Jomo, 1997; Johnson \& Mitton, 2003; Marzuki \& Wahab, 2016; Mohammed, Ahmed, \& Ji, 2017).

Malaysia was one of the countries hardest hit by the 1997/1998 Asian financial crisis. The financial crisis highlighted the need for better corporate governance practice in the country. In March 2000, the Malaysian government issued the MCCG to improve the country's corporate governance practice. In addition, as part of a broader capital market framework, the Minority Shareholders Watchdog Group (MSWG) was formed in 2000 as a government initiative to protect the interest of minority shareholders through shareholder activism. In January 2001, MCCG became part of the listing requirements for Bursa Malaysia, which requires all publicly listed firms to disclose the extent of their compliance with MCCG. This signifies a pivotal moment in the history of Malaysia's corporate governance practice.

Malaysia's unique institutional environment, together with the inclusion of MCCG in Bursa Malaysia listing rules in 2001, offers a suitable setting for examining the role of corporate governance reform and political connections on accounting conservatism.

Prior studies have examined the association between corporate governance and earnings conservatism in Malaysia, and whether the revised MCCG in 2007 improves accounting conservatism (Marzuki, Wahab, \& Haron, 2016). Further, prior studies have examined the relationship between accounting conservatism, corporate governance, and political connections of large firms' in Malaysia from 2004 to 2007 (Mohammed et al., 2017). Finally, prior studies have examined the impact of MCCG on corporate governance practice (Wahab, How, \& Verhoeven, 2007) and the impact of MCCG on financial reporting lag (Lim, How, \& Verhoeven, 2014). To the best of our knowledge, there has not been a study that examines the impact of the integration of the original MCCG into Bursa Malaysia listing rules in 2001 on accounting conservatism in Malaysia. Our study is intended to fill this void.

This study finds evidence that MCCG inclusion into Bursa Malaysia listing requirements in 2001 improves accounting conservatism. Further analysis reveals that prior to MCCG, firms with political connections (PC firms, hereafter) do not exhibit accounting conservatism, and firms without political connections (non-PC firms, hereafter) exhibit accounting conservatism. After the MCCG, both PC and non-PC firms show accounting conservatism, and more interestingly, PC firms demonstrate more timely loss recognition (greater accounting conservatism) compared to non-PC firms.

These results support the view that prior to MCCG, PC firms have less incentive for accounting conservatism (timely recognition of economic income, especially losses, into accounting income) because they have a lesser need to respond to market demand for quality financial reporting. PC firms also might receive less stringent regulatory oversight and negative consequences for poor quality reporting After MCCG is included in the listing rules, however, there is an overall increase in the demand for better financial reporting quality, including the demand for accounting conservatism. In addition, with the establishment of MSWG to improve shareholders' activism in protecting minority shareholders, PC firms may be more susceptible to public scrutiny, and thus responded by significantly improving their accounting conservatism.

We extend the literature on accounting conservatism in Malaysia by providing evidence of the impact of the MCCG inclusion in Bursa Malaysia listing rules on accounting conservatism. Because the implementation of MCCG is exogenous, our study is not plagued by the endogeneity problem in corporate governance studies. This study also extends a growing literature on "relationship-based" economies, specifically literature on the relationship between political connections and reporting quality.

The remainder of this paper is organized as follows. The next section provides background on accounting conservatism and corporate governance, political connections in Malaysia, and MCCG. The 
subsequent sections provide hypotheses development, research designs and empirical results. The final section provides conclusions.

\section{BACKGROUND}

\section{Accounting Conservatism and Corporate Governance}

Accounting conservatism has influenced accounting practice for the last five hundred years (Basu, 1997), and it is considered the most influential principle in accounting valuation (Sterling, 1970). Basu (1997) defines accounting conservatism as the extent to which current-period accounting income asymmetrically incorporates economic losses, relative to economic gains. Accounting conservatism enhances financial statement usefulness by reducing agency problems, constraining managers' opportunistic behavior related to payments to themselves and to other parties, increasing the efficiency of contracts with debt holders and management, facilitating the monitoring of contracts, and reducing litigation costs (Ball \& Shivakumar, 2005; Garcia Lara, Osma, \& Penalva, 2009; Watts, 2003a, 2003b).

Corporate governance is important in the development of a capital market. It provides a monitoring mechanism to ensure that management used the firm's assets efficiently, and to prevent inappropriate distribution of these assets to managers or other parties at the expense of the rest of the stakeholders (Garcia Lara et al., 2009; Shleifer \& Vishny, 1997).

Prior studies have shown a positive association between strong corporate governance mechanism and accounting conservatism (Ahmed \& Duellman, 2007; Ahmed \& Henry, 2012; Beekes, Pope, \& Young, 2004; Garcia Lara et al., 2009; Marzuki et al., 2016; Mohammed et al., 2017). Because sound corporate governance results in better monitoring of the management, and the roles of accounting conservatism include mitigating agency costs and reducing litigation risk, it is expected that better corporate governance mechanism would desire accounting conservatism, i.e., conservatism will provide early warning signals to governance bodies and promote early investigations to the reasons for bad news (Garcia Lara et al., 2009).

\section{Political Connections in Malaysia}

Malaysia's economy is characterized by significant political connections in business, unequal distribution of wealth, corruption, and the abuse of power (Gomez \& Jomo, 1997). One major factor that contributes to the political connections in Malaysia is the government's initiation of the New Economic Policy (NEP) in 1970 as a response to ethnic riots in 1969. The riots were triggered by an economic imbalance between ethnic Chinese and Malay (Bumiputera). Ethnic Chinese, who are the minority, have historically dominated the economy in Malaysia. Bumiputera, who account for 61 percent of the Malaysian population, held only 2.4 percent of the economic wealth (Gomez \& Jomo, 1997). The NEP was intended to correct this imbalance by giving the Bumiputeras special privileges such as priority for government contracts, increased access to capital, and other subsidies. The government also created Bumiputera trust agencies under the direction of the United Malay National Organization (UMNO). By the 1990s, many companies owned and managed by UMNO had emerged. These companies often receive special privileges from the government, such as easy access to financing, government contracts, subsidies, etc.

As the government increased its involvement in business by granting favors to Bumiputras' firms, other businessmen (Malay, Chinese, and Indians) became more active in using their personal connections with politicians to influence the allocations of those favors (Gomez \& Jomo, 1997). This created another type of political favoritism, which is based on informal ties between politicians and businessmen (Gul, 2006). By the 1990s, the Malaysian corporate sector was dominated by politically-connected firms (Gul, 2006). Faccio (2006) finds that more than 10 percent of firms in Malaysia are politically connected, and they account for more than 10 percent of the market capitalization. 


\section{MCCG and Malaysia Corporate Governance Reform}

The 1997/1998 Asian financial crisis exposed a number of poor corporate governance practices in Malaysia, such as over-leveraging (Fraser, Zhang, \& Derashid, 2006); lack of transparency, financial disclosure and accountability (Mitton, 2002); poor legal protection of minority investors against expropriation by corporate insiders (Claessens, Djankov, Fan, \& Lang,1999); and cronyism (Johnson \& Mitton, 2003). These problems were intensified by the existence of an extensive network of politically connected firms and lack of shareholders' activism by local institutional shareholders (Wahab et al., 2007). A joint survey conducted by the Kuala Lumpur Stock Exchange (now Bursa Malaysia) and PwC indicated that 94 percent of firms in Malaysia desired a corporate governance reform (Finance Committee on Corporate Governance, 1999).

The most significant event in institutionalizing Malaysian corporate governance reforms is the creation of the High Level Finance Committee on Corporate Governance (FCCG) in 1998 (Leong, 2005). FCCG recommended the passage of the Malaysian Code on Corporate Governance (MCCG) in March 2000 to improve the country's corporate governance practice and regain investors' confidence. MCCG aims to set out principles and best practices on corporate governance structures and processes that companies may use to achieve the optimal governance framework (FCCG, 2000). FCCG also recommended the establishment of the Minority Shareholders Watchdog Group (MSWG), whose main objective is to monitor and prevent insiders' abuses against the minority shareholders (FCCG, 1999).

MCCG consists of four parts. Part 1 sets forth broad principles of good corporate governance. These principles include the composition (balance between executive and non-executive directors), appointment and re-election process of the board of directors; the level, procedures and disclosure of directors' remuneration; communication between the company and their shareholders; accountability and audit. Part 2 identifies a set of best practices or guidelines aimed to assist companies in designing their approach to corporate governance. Part 3 encourages other market participants (e.g., investors, auditors) to improve their role in corporate governance. Part 4 provides explanatory notes.

MCCG went through a brief self-regulatory (voluntary or non-statutory) period before finally became part of Bursa Malaysia listing rules in 2001. Companies listed on Bursa Malaysia are required to disclose in their annual report, a narrative statement of how they apply the relevant principles set out in Part 1, the extent to which they complied with the best practices identified in Part 2, and justifications of any departure from the guidelines set out in Part 2. The inclusion of MCCG in Bursa Malaysia listing requirements in 2001 signifies a pivotal moment in the history of Malaysia's corporate governance regulation and practice.

Since its introduction in 2000, MCCG has been reviewed and refined in 2007, 2012, and 2017. This paper examines the impact of the original MCCG on accounting conservatism.

\section{HYPOTHESES DEVELOPMENT}

The mandatory adoption of the MCCG in 2001, together with the increased participation of minority shareholders in the corporate governance through the MSWG, provides a unique opportunity to investigate the effect of corporate governance reform on accounting conservatism in Malaysia. Using data from 1999 to 2002, Wahab et al. (2007) find an improvement in the corporate governance practice in Malaysia after the integration of MCCG in Bursa Malaysia. Using data from 2004-2009, Marzuki et al. (2016) find that the MCCG revision in 2007 increased accounting conservatism. To the best of our knowledge, however, there is no prior study examining the impact of the initial MCCG on accounting conservatism in Malaysia.

An important and unique institutional feature of Malaysia's economy is the dominance of political connections in the economy, where firms with close relationships with the government or powerful political figures receive many benefits from their political connections (e.g., preferential access to financing, priority to receive government contracts, more relaxed regulatory oversights, etc.). In such relationship-based economic systems, the system generally is characterized by weak legal enforcement and lack of transparency (Rajan \& Zingales, 1998). Relationship-based systems can survive in an 
environment where contracts are poorly enforced because relationships substitute for contracts in governing transactions. In addition, relationship-based systems prefer opacity to protect the relationships from the threat of competition. Information asymmetry is resolved more likely by "insider" communication with stakeholder representatives, so there is a lower demand for high quality public financial reporting and disclosure, including the demand for accounting conservatism (Ball et al., 2003).

In an arm-length, market-oriented, economic system with the "shareholder" model, generally there is a more diverse base of individual shareholders and bondholders, and information asymmetry is resolved more efficiently through public disclosure. This creates a larger demand for higher quality financial reports, including more timely incorporation of economic income in accounting income. The asymmetric loss function of debt holders implies a particular demand for earnings conservatism, because timely recognition of economic losses makes existing leverage and coverage covenants binding more quickly (Ball et al., 2003).

There are two competing views on the relationship between political connections and accounting conservatism. The first view suggests a negative correlation between political connections and accounting conservatism based on several arguments. First, political connections may substitute for contracts in governing transactions, and information asymmetry is resolved more extensively through private communication than through public disclosures. These create less incentive for PC firms to produce high quality financial reports, including timely recognition of economic losses (accounting conservatism), because there is no pressure or demand for these firms to produce high quality financial reports. In addition, PC firms may receive less negative consequences for low financial reporting quality and less stringent regulatory oversight from the government and market regulators, creating less incentive for timely loss recognition. Firms without political connections, on the other hand, may have greater incentives to adopt a corporate strategy consistent with an arm's-length system, which demands higher reporting quality and transparency, and more timely loss recognition (Bushman et al., 2004; Leuz and Oberholzer-Gee, 2006).

Prior studies have found evidence of negative association between political connections and financial reporting quality. Chaney, Faccio, and Parsley (2011) find a negative association between accruals quality and political connections, and a negative association between accruals quality and cost of debt for PC firms. These results suggest that PC firms face fewer negative consequences (in terms of cost of debt capital) of lower reporting quality. Mohammed et al. (2017) find a negative association between the proportion of politically-connected board of directors and accounting conservatism. This result further supports the view that timely recognition of economic losses that generally is very crucial in debt contract, is not as important for PC firms due to their relatively easier access to financing and lower cost of debt.

The second view suggests a positive association between political connections and accounting conservatism. The argument for this view is that PC firms adopt a more conservative accounting numbers to avoid increased public scrutiny (Bushman \& Piotroski, 2006; Watts, 2003a). Another argument supporting this view is that $\mathrm{PC}$ firms report more conservative accounting income to reduce expropriation risk by the government or connected politicians.

The corporate governance reform calls for changes in financial reporting and corporate governance practice in Malaysia. The inclusion of MCCG in Bursa Malaysia listing requirements and the establishment of the MSWG put pressure on firms in Malaysia to improve their reporting practice. In this study we conjecture that the inclusion of MCCG in Bursa Malaysia listing requirements in 2001 increases accounting conservatism.

H1: Firms in Malaysia exhibit greater accounting conservatism after MCCG is included in Bursa Malaysia listing requirements in 2001.

Further, based on the above discussion, we predict that the inclusion of MCCG in Bursa Malaysia listing requirements will have a different impact on PC firms' accounting conservatism compared to nonPC firms. 
H2: The extent of improvement in accounting conservatism due to MCCG is different for PC firms compared to non-PC firms.

\section{RESEARCH DESIGN}

\section{Sample}

The sample consists of publicly-listed companies in Malaysia during 1988-2006 that have the required accounting and return data to calculate all of the empirical variables in this study. We do not include data beyond 2006 to avoid any potential impact of the revised MCCG in 2007 on our results.

Accounting data is obtained from Compustat Global Industrial/Commercial (IC) file, returns data is obtained from Compustat Global Issues file, and political connections data is based on the data developed by Faccio (2006). Faccio (2006) classifies a firm as a PC firm if one of the firm's large shareholders (who controls at least 10 percent of the votes) or top officers (Chief Executive Officer, President, Vice President, or Secretary) is a member of parliament, a minister, or a head of state (or their close relative), or is closely related to a top government official. We hold the political connection status of a firm constant throughout the period of the study. To ensure there are no changes in the status of a firm's political connectedness, especially from politically connected to non-politically connected, we merge our PC firms list with the PC firms list from Fung et al. (2015), which looks at firms' political connection that exists through 2007.

Table 1 describes the sample selections. The final sample size is 5,650 firm-year observations, after removing (i) observations with missing data, (ii) observations with negative equity, and (iii) the $1^{\text {st }}$ and $100^{\text {th }}$ percentiles of net income. Firms with negative equity were removed because these firms are by definition bankrupt, therefore the inclusion of these firms potentially could confound the results. The $1^{\text {st }}$ and $100^{\text {th }}$ percentiles of net income were removed to reduce the effect of outliers.

TABLE 1

SAMPLE DESCRIPTION

\begin{tabular}{lrrr}
\hline & Pre-MCCG & Post-MCCG & Total \\
\hline Initial firm-year observations & 10,098 & 4,706 & 14,804 \\
Less: observation with missing data & 7,477 & 1,355 & 8,832 \\
Less: observation with negative total equity & 97 & 109 & 206 \\
Less: $1^{\text {st }}$ and $100^{\text {th }}$ percentiles of net income (NI) & 46 & 70 & 116 \\
\hline \multicolumn{1}{c}{ Total } & $\mathbf{2 , 4 7 8}$ & $\mathbf{3 , 1 7 2}$ & $\mathbf{5 , 6 5 0}$ \\
\hline PC firms & 349 & 243 & 592 \\
Non PC firms & 2,129 & 2,929 & 5,058 \\
\hline \multicolumn{1}{c}{ Total } & $\mathbf{2 , 4 7 8}$ & $\mathbf{3 , 1 7 2}$ & $\mathbf{5 , 6 5 0}$ \\
\hline
\end{tabular}

Pre-MCCG = period before the integration of MCCG into Bursa Malaysia listing rules (1988-2000); Post-MCCG = period after the integration of MCCG into Bursa Malaysia listing rules (2001-2006); PC firms = firms with political connections; Non-PC firms = firms without political connections.

\section{Model Specifications}

We use Basu's (1997) model as our main measure of accounting conservatism. Basu (1997) uses annual stock returns as proxies for economic income. Basu's (1997) model uses the following reverse regression model to measure the timeliness (speed) of good news (positive returns) and bad news (negative returns) recognition into accounting income: 
where NEG is an indicator variable equal to 1 if returns are negative, and 0 otherwise. Following Ball et.al. (2003), the earnings variable (NI) is measured by net income before extraordinary items divided by the number of shares outstanding, adjusted for stock splits and stock dividends. To help control for heteroskedasticity, accounting income is scaled by the beginning stock price (Christie, 1987). Stock return (RET) is measured as the 12-month holding period returns, including dividends, over the firm's fiscal year.

In the Basu's (1997) model, $\beta_{2}$ captures the speed of any news recognition and $\beta_{3}$ captures' the incremental speed of bad news recognition relative to the speed of good news recognition in accounting income. If $\beta_{3}=0$, there is no difference between the speed of good news recognition and the speed of bad news recognition. However, if $\beta_{3} \neq 0$, then $\beta_{2}$ captures the speed of good news recognition, $\beta_{3}$ captures the incremental speed of bad news recognition relative to good news recognition, and $\beta_{2}+\beta_{3}$ captures the speed of bad news recognition. If $\beta_{3}>0$, accounting income is more sensitive to bad news than to good news, which indicates accounting conservatism. For the remainder of the paper, we focus on the incremental speed of bad news recognition into accounting income, i.e., coefficient on NEG*RET $\left(\beta_{3}\right)$ and its variations.

To test the difference in accounting conservatism before and after MCCG is included in Bursa Malaysia listing rules, we run Basu's (1997) model with a post-MCCG dummy variable as an interaction variable:

$$
\begin{aligned}
N I_{i t} & =\beta_{0}+\beta_{1} N E G_{i t}+\beta_{2} R E T_{i t}+\beta_{3} N E G_{i t} * R E T_{i t}+\beta_{4} P O S T_{i t}+\beta_{5} P O S T_{i t} * N E G_{i t} \\
& +\beta_{6} P O S T_{i t} * R E T_{i t}+\beta_{7} P O S T_{i t} * N E G_{i t} * R E T_{i t}+\varepsilon_{i t}
\end{aligned}
$$

where POST is an indicator variable equal to 1 for fiscal years 2001 and later (post-MCCG period), and 0 otherwise (pre-MCCG period). We run regression model (2) separately for the all firms sample, the PC firms sample, and the non-PC firms sample.

In addition, we run the regression on the pooled sample of PC and non-PC firms with a political connection dummy variable interacting with each variable in model (2). The pooled cross-sectional regression allows us to examine the statistical significance of differences in accounting conservatism between the two groups of firms. The pooled cross-sectional regression model is as follows:

$$
\begin{aligned}
N I_{i t} & =\beta_{0}+\beta_{1} N E G_{i t}+\beta_{2} R E T i t+\beta_{3} N E G_{i t} * R E T_{i t}+\beta_{4} P C+\beta_{5} P C_{i t} * N E G_{i t}+\beta_{6} P C_{i t} * R E T_{i t} \\
& +\beta_{7} P C_{i t} * N E G_{i t} * R E T_{i t}+P O S T *\left(\beta_{0}+\beta_{1} N E G_{i t}+\beta_{2} R E T i t+\beta_{3} N E G_{i t} * R E T_{i t}+\beta_{4} P C\right. \\
& \left.+\beta_{5} P C_{i t} * N E G_{i t}+\beta_{6} P C_{i t} * R E T_{i t}+\beta_{7} P C_{i t} * N E G_{i t} * R E T_{i t}\right)+\varepsilon_{i t}
\end{aligned}
$$

where $\mathrm{PC}$ is an indicator variable equal to 1 for firms with political connections, and 0 otherwise.

\section{Control for Size, Leverage, and Growth}

Prior studies suggest that firm size, leverage, and growth affect earnings conservatism (Beekes et al., 2004). Therefore, these variables are added as control variables in the regression model. Firm size (SIZE) is measured as the log of market value of equity at the beginning of the period. Leverage (LEV) is measured as total debt divided by total equity at the beginning of the period. Firm growth (PB) is measured by the price-to-book ratio (market value divided by total equity) at the beginning of the period. We run models 2 and 3 with each control variable interacted with variables NEG, RET, and NEG*RET.

\section{Accrual-based Accounting Conservatism Measure}

We adopted Ball and Shivakumar (2005) accrual-based loss recognition model as our second measure of accounting conservatism. This model incorporates the recognition of unrealized gains and losses via accruals. The asymmetric recognition of gains or losses in this model arises because economic losses are more likely to be recognized on a timely basis as unrealized, non-cash, accrued charges against income. 
Economic gains are more likely to be recognized when realized, and therefore accounted for on a cash basis (Ball \& Shivakumar, 2005). Ball and Shivakumar (2005) estimate a piecewise linear relation between cash flow and accruals as follows:

$A C C_{i t}=\beta_{0}+\beta_{1} D C F O_{i t}+\beta_{2} C F O_{i t}+\beta_{3} D C F O_{i t} * C F O_{i t}+\varepsilon_{i t}$

where $A C C_{i t}$ is accruals scaled by total assets at the beginning of the period. Accruals are measured as the difference between net income before extraordinary items minus cash flows from operation. $C F O_{i t}$ is the operating cash flows, also standardized by the beginning total assets. $D C F O_{i t}$ is a dummy variable that takes the value of 1 if the $C F O_{i t}$ is negative, and 0 otherwise. A positive coefficient on $D C F O * C F O$ indicates a more timely loss recognition, i.e. accounting conservatism.

We test our hypothesis using the following modified Ball and Shivakumar (2005) model:

$$
\begin{aligned}
& A C C_{i t}=\beta_{0}+\beta_{1} D C F O_{i t}+\beta_{2} C F O_{i t}+\beta_{3} D C F O_{i t} * C F O_{i t}+\beta_{4} P C+\beta_{5} P C_{i t} * D C F O_{i t} \\
& +\beta_{6} P C_{i t} * C F O_{i t}+\beta_{7} P C_{i t} * D C F O_{i t} * C F O_{i t}+P O S T *\left(\beta_{0}+\beta_{1} D C F O_{i t}+\beta_{2} C F O_{i t}\right. \\
& \left.+\beta_{3} D C F O_{i t} * C F O_{i t}+\beta_{4} P C+\beta_{5} P C_{i t} * D C F O_{i t}+\beta_{6} P C_{i t} * C F O_{i t}+\beta_{7} P C_{i t} * D C F O_{i t} * C F O_{i t}\right) \\
& +g_{k} \text { Controls }_{i t}\left(D_{C F O}+\mathrm{CFO}_{i t}+\mathrm{DCFO}_{i t} * C F O_{i t}\right)+\varepsilon_{i t}
\end{aligned}
$$

Similar to our main test using the Basu (1997) model, we run this regression controlling for size, leverage, and growth. For our analysis, we focus on the incremental speed of unrealized accrued charges recognition into income, i.e. the coefficient on $\mathrm{DCFO} * \mathrm{CFO}$ and its variations.

\section{EMPIRICAL RESULTS}

\section{Descriptive Statistics}

Table 2 contains sample descriptive statistics. Table 2 Panel A shows the difference in means between PC firms and non-PC firms for the entire sample period (1988-2006). PC firms report significantly higher net income (8.38 versus 4.47 ), are larger in size (26.03 versus 9.00 ), and have higher leverage $(2.05$ versus 1.40$)$. These differences are statistically significant at the $1 \%$ or $5 \%$ significance level. The standard deviations for net income are larger for PC firms than for non-PC firms (30.32 and 19.11, respectively), indicating that PC firms' net income is more volatile than that of their non-PC peers.

Table 2 Panels $\mathrm{B}$ and $\mathrm{C}$ show the differences in means between the two firm groups for the periods before the MCCG (1988-2000), and after the MCCG (2001-2006). In the pre-MCCG period (Panel B), PC firms on average are significantly larger in size compared to non-PC firms (38.95 and 12.49, respectively); however, there are no statistically significant differences in the net income, returns, leverage, and price-to-book ratio between the two groups. In the post-MCCG period (Panel C), PC firms on average show higher net income, larger size, higher leverage, and larger price-to-book ratio compared to non-PC firms. 
TABLE 2

DESCRIPTIVE STATISTICS

\begin{tabular}{|c|c|c|c|c|c|c|c|c|c|c|}
\hline \multicolumn{11}{|c|}{ Panel A: Full Sample Period (1988-2006) } \\
\hline & \multicolumn{3}{|c|}{ PC firms $(N=592)$} & \multicolumn{3}{|c|}{ Non-PC firms $(\mathrm{N}=5,058)$} & \multicolumn{4}{|c|}{ T-test } \\
\hline Variable & Mean & SD & $\begin{array}{c}\text { Media } \\
\text { n }\end{array}$ & Mean & SD & Median & Pooled & $\begin{array}{c}\text { p- } \\
\text { value }\end{array}$ & $\begin{array}{c}\text { Satterth } \\
\text { waite }\end{array}$ & $\begin{array}{c}\text { p- } \\
\text { value }\end{array}$ \\
\hline$N I$ & 8.38 & 30.32 & 5.04 & 4.47 & 19.11 & 1.13 & 4.38 & $<.0001$ & -3.07 & 0.00 \\
\hline RET & 0.13 & 0.74 & -0.01 & 0.11 & 0.70 & -0.01 & -0.70 & 0.49 & -0.67 & 0.50 \\
\hline SIZE & 26.03 & 149.71 & 6.04 & 9.00 & 14.59 & 4.88 & -7.79 & $<.0001$ & -2.77 & 0.01 \\
\hline$L E V$ & 2.05 & 5.25 & 1.13 & 1.40 & 12.68 & 0.77 & -1.25 & 0.21 & -2.35 & 0.02 \\
\hline$P B$ & 0.13 & 0.76 & 0.01 & 0.13 & 1.02 & 0.04 & 0.01 & 0.99 & 0.01 & 0.99 \\
\hline \multicolumn{11}{|c|}{ Panel B: Pre-MCCG Period (1988-2000) } \\
\hline & \multicolumn{3}{|c|}{ PC firms $(N=349)$} & \multicolumn{3}{|c|}{ Non-PC firms $(\mathrm{N}=2,129)$} & \multicolumn{4}{|c|}{ T-test } \\
\hline Variable & Mean & SD & $\begin{array}{c}\text { Media } \\
\text { n }\end{array}$ & Mean & SD & Median & Pooled & $\begin{array}{c}\text { p- } \\
\text { value }\end{array}$ & $\begin{array}{c}\text { Satterth } \\
\text { waite }\end{array}$ & $\begin{array}{c}\text { p- } \\
\text { value }\end{array}$ \\
\hline$N I$ & 6.11 & 26.59 & 4.23 & 4.43 & 17.26 & 1.16 & -1.54 & 0.12 & -1.14 & 0.26 \\
\hline RET & 0.14 & 0.86 & -0.03 & 0.15 & 0.87 & -0.02 & 0.13 & 0.90 & 0.13 & 0.90 \\
\hline SIZE & 38.95 & 193.90 & 7.22 & 12.49 & 19.32 & 6.88 & -6.12 & $<.0001$ & -2.55 & 0.01 \\
\hline$L E V$ & 2.05 & 4.12 & 1.21 & 1.77 & 14.14 & 0.87 & -0.36 & 0.72 & -0.73 & 0.47 \\
\hline$P B$ & 0.20 & 0.97 & 0.02 & 0.22 & 1.51 & 0.04 & 0.27 & 0.79 & 0.36 & 0.72 \\
\hline \multicolumn{11}{|c|}{ Panel C: Post-MCCG Period (2001-2006) } \\
\hline & \multicolumn{3}{|c|}{ PC firms $(N=243)$} & \multicolumn{3}{|c|}{ Non-PC firms $(\mathrm{N}=\mathbf{2 , 9 2 9})$} & \multicolumn{4}{|c|}{ T-test } \\
\hline Variable & Mean & SD & $\underset{\mathbf{n}}{\text { Media }}$ & Mean & SD & Median & Pooled & $\begin{array}{c}\text { p- } \\
\text { value }\end{array}$ & $\begin{array}{l}\text { Satterth } \\
\text { waite }\end{array}$ & $\begin{array}{c}\text { p- } \\
\text { value }\end{array}$ \\
\hline$N I$ & 11.64 & 34.78 & 7.31 & 4.50 & 20.35 & 1.10 & -4.91 & $<.0001$ & -3.16 & 0.00 \\
\hline RET & 0.11 & 0.51 & 0.04 & 0.07 & 0.55 & 0.00 & -0.88 & 0.38 & -0.93 & 0.35 \\
\hline SIZE & 7.48 & 9.10 & 4.24 & 6.47 & 9.02 & 3.90 & -1.68 & 0.09 & -1.67 & 0.10 \\
\hline$L E V$ & 2.06 & 6.55 & 0.98 & 1.12 & 11.50 & 0.71 & -1.26 & 0.21 & -2.00 & 0.05 \\
\hline$P B$ & 0.04 & 0.19 & 0.01 & 0.07 & 0.33 & 0.04 & 1.44 & 0.15 & 2.23 & 0.03 \\
\hline
\end{tabular}




\section{Correlations}

Table 3 reports on the bivariate statistical correlations for the full sample period (1988-2006), preMCCG period (1988-2000), and post-MCCG period (2001-2006). In general, net income is positively correlated with returns, and negatively correlated with price-to-book ratio; returns are negatively correlated with size and price-to-book ratio; and price-to-book ratio is positively correlated with size and leverage. Most of these correlations remain consistent when we segregate the sample into pre- and postMCCG periods, as well as PC and non-PC firms.

TABLE 3

PEARSON CORRELATION

\begin{tabular}{|c|c|c|c|c|c|c|c|c|c|c|c|c|}
\hline \multicolumn{13}{|c|}{ Panel A: All Firms } \\
\hline \multicolumn{5}{|c|}{ Full sample period $(\mathrm{N}=5,650)$} & \multicolumn{4}{|c|}{ Pre- MCCG $(\mathrm{N}=2,478)$} & \multicolumn{4}{|c|}{ Post-MCCG $(\mathrm{N}=3,172)$} \\
\hline & RET & SIZE & LEV & PB & RET & SIZE & LEV & PB & RET & SIZE & LEV & PB \\
\hline \multirow[t]{2}{*}{ NI } & 0.13 & $(0.01)$ & $\begin{array}{r}(0.01 \\
)\end{array}$ & $(0.03)$ & 0.09 & $(0.02)$ & $\begin{array}{r}(0.02 \\
)\end{array}$ & $(0.04)$ & 0.18 & 0.04 & 0.00 & $(0.04)$ \\
\hline & $\begin{array}{r}<.000 \\
1\end{array}$ & 0.41 & 0.51 & 0.03 & $\begin{array}{r}<.000 \\
1\end{array}$ & 0.25 & 0.25 & 0.09 & $\begin{array}{r}<.000 \\
1\end{array}$ & 0.05 & 0.88 & 0.02 \\
\hline \multirow[t]{2}{*}{ RET } & & $(0.05)$ & $\begin{array}{r}(0.01 \\
)\end{array}$ & $(0.05)$ & & $(0.06)$ & $\begin{array}{r}(0.02 \\
)\end{array}$ & $(0.05)$ & & $\begin{array}{r}(0.04 \\
)\end{array}$ & $\begin{array}{r}(0.01 \\
)\end{array}$ & $(0.05)$ \\
\hline & & 0.00 & 0.40 & 0.00 & & 0.00 & 0.37 & 0.01 & & 0.03 & 0.78 & 0.01 \\
\hline \multirow[t]{2}{*}{ SIZE } & & & $\begin{array}{r}(0.00 \\
)\end{array}$ & 0.32 & & & $\begin{array}{r}(0.00 \\
)\end{array}$ & 0.32 & & & $\begin{array}{r}(0.01 \\
)\end{array}$ & 0.12 \\
\hline & & & 0.92 & $\begin{array}{r}<.000 \\
1\end{array}$ & & & 0.84 & $\begin{array}{r}<.000 \\
1\end{array}$ & & & 0.64 & $\begin{array}{r}<.000 \\
1\end{array}$ \\
\hline \multirow[t]{2}{*}{ LEV } & & & & 0.15 & & & & 0.12 & & & & 0.42 \\
\hline & & & & $\begin{array}{r}<.000 \\
1\end{array}$ & & & & $\begin{array}{r}<.000 \\
1\end{array}$ & & & & $\begin{array}{r}<.000 \\
1\end{array}$ \\
\hline \multicolumn{13}{|c|}{ Panel B: PC Firms } \\
\hline \multicolumn{5}{|c|}{ Full sample period $(\mathrm{N}=592)$} & \multicolumn{4}{|c|}{ Pre- MCCG $(\mathrm{N}=349)$} & \multicolumn{4}{|c|}{ Post-MCCG (N=243) } \\
\hline & RET & SIZE & LEV & PB & RET & SIZE & LEV & PB & RET & SIZE & LEV & PB \\
\hline \multirow[t]{2}{*}{ NI } & 0.10 & $(0.03)$ & $\begin{array}{r}(0.00 \\
)\end{array}$ & $(0.04)$ & 0.10 & $(0.04)$ & $\begin{array}{r}(0.13 \\
)\end{array}$ & $(0.04)$ & 0.14 & 0.04 & 0.09 & $(0.05)$ \\
\hline & 0.01 & 0.42 & 0.99 & 0.28 & 0.07 & 0.49 & 0.02 & 0.42 & 0.03 & 0.59 & 0.18 & 0.40 \\
\hline \multirow[t]{2}{*}{ RET } & & $(0.05)$ & 0.05 & $(0.04)$ & & $(0.06)$ & 0.07 & $(0.04)$ & & $\begin{array}{r}(0.00 \\
)\end{array}$ & 0.03 & $(0.11)$ \\
\hline & & 0.19 & 0.27 & 0.35 & & 0.24 & 0.21 & 0.49 & & 0.98 & 0.69 & 0.08 \\
\hline \multirow[t]{2}{*}{ SIZE } & & & $\begin{array}{r}(0.02 \\
)\end{array}$ & 0.87 & & & $\begin{array}{r}(0.03 \\
)\end{array}$ & 0.88 & & & $\begin{array}{r}(0.02 \\
)\end{array}$ & 0.06 \\
\hline & & & 0.61 & $\begin{array}{r}<.000 \\
1\end{array}$ & & & 0.52 & $\begin{array}{r}<.000 \\
1\end{array}$ & & & 0.82 & 0.33 \\
\hline \multirow[t]{2}{*}{ LEV } & & & & 0.12 & & & & 0.17 & & & & 0.16 \\
\hline & & & & 0.00 & & & & 0.00 & & & & 0.02 \\
\hline
\end{tabular}




\begin{tabular}{|c|c|c|c|c|c|c|c|c|c|c|c|c|}
\hline \multicolumn{13}{|c|}{ Panel C: Non-PC Firms } \\
\hline \multicolumn{5}{|c|}{ Full sample period $(\mathrm{N}=5,058)$} & \multicolumn{4}{|c|}{ Pre- MCCG $(\mathrm{N}=2,129)$} & \multicolumn{4}{|c|}{ Post-MCCG $(\mathrm{N}=2,929)$} \\
\hline & RET & SIZE & LEV & PB & RET & SIZE & LEV & PB & RET & SIZE & LEV & PB \\
\hline \multirow[t]{2}{*}{ NI } & 0.13 & $(0.01)$ & $\begin{array}{r}(0.01 \\
)\end{array}$ & $(0.03)$ & 0.09 & $(0.04)$ & $\begin{array}{r}(0.02 \\
)\end{array}$ & $(0.04)$ & 0.19 & 0.03 & $\begin{array}{r}(0.01 \\
)\end{array}$ & $(0.04)$ \\
\hline & $\begin{array}{r}<.000 \\
1\end{array}$ & 0.58 & 0.43 & 0.05 & $\begin{array}{r}<.000 \\
1\end{array}$ & 0.07 & 0.40 & 0.11 & $\begin{array}{r}<.000 \\
1\end{array}$ & 0.08 & 0.74 & 0.03 \\
\hline \multirow[t]{2}{*}{ RET } & & $(0.13)$ & $\begin{array}{r}(0.02 \\
)\end{array}$ & $(0.05)$ & & $(0.18)$ & $\begin{array}{r}(0.02 \\
)\end{array}$ & $(0.06)$ & & $\begin{array}{r}(0.04 \\
)\end{array}$ & $\begin{array}{r}(0.01 \\
)\end{array}$ & $(0.04)$ \\
\hline & & $\begin{array}{r}<.000 \\
1\end{array}$ & 0.30 & 0.00 & & $\begin{array}{r}<.000 \\
1\end{array}$ & 0.30 & 0.01 & & 0.02 & 0.72 & 0.02 \\
\hline \multirow[t]{2}{*}{ SIZE } & & & $\begin{array}{r}(0.00 \\
)\end{array}$ & 0.43 & & & $\begin{array}{r}(0.01 \\
)\end{array}$ & 0.48 & & & $\begin{array}{r}(0.01 \\
)\end{array}$ & 0.12 \\
\hline & & & 0.95 & $\begin{array}{r}<.000 \\
1\end{array}$ & & & 0.82 & $\begin{array}{r}<.000 \\
1\end{array}$ & & & 0.63 & $\begin{array}{r}<.000 \\
1\end{array}$ \\
\hline \multirow[t]{3}{*}{ LEV } & & & & 0.16 & & & & 0.12 & & & & 0.42 \\
\hline & & & & $<.000$ & & & & $<.000$ & & & & $<.000$ \\
\hline & & & & 1 & & & & 1 & & & & 1 \\
\hline $\begin{array}{l}\mathrm{NI} \text { is n } \\
\text { holding } \\
\mathrm{LEV} \text { is } \\
\text { in italic }\end{array}$ & $\begin{array}{l}\text { income } \\
\text { eriod re } \\
\text { rm's les } \\
\text { eprese }\end{array}$ & $\begin{array}{l}\text { oefore ex } \\
\text { urn incl } \\
\text { erage as } \\
\text { t p-value }\end{array}$ & $\begin{array}{l}\text { traordin } \\
\text { ding div } \\
\text { measure }\end{array}$ & $\begin{array}{l}\text { y items } \\
\text { dends o } \\
\text { by total }\end{array}$ & $\begin{array}{l}\text { aled by } \\
\text { the fir } \\
\text { abilities }\end{array}$ & $\begin{array}{l}\text { he mark } \\
\text { l's fiscal } \\
\text { divided }\end{array}$ & $\begin{array}{l}\text { value } \\
\text { ear; } \mathrm{SI} \\
\text { total e }\end{array}$ & $\begin{array}{l}\text { the beg } \\
\mathrm{E} \text { is the } \\
\text { uity; } \mathrm{PE}\end{array}$ & $\begin{array}{l}\text { ning of } \\
\text { rm's na } \\
\text { s price- }\end{array}$ & $\begin{array}{l}\text { the year } \\
\text { ural log } \\
\text { o-book }\end{array}$ & $\begin{array}{l}\text { RET is } \\
\text { f total } \\
\text { atio. N }\end{array}$ & $\begin{array}{l}\text { he } \\
\text { ssets; } \\
\text { hbers }\end{array}$ \\
\hline
\end{tabular}

\section{Regression Results}

Table 4 shows the results from regression model (2) for all firms' samples during the pre-MCCG, post-MCCG, and full sample periods (Panels A, B, and C, respectively). In both pre- and post-MCCG periods, the coefficients on NEG*RET are positive and statistically significant, indicating that, on average, firms in Malaysia exhibit accounting conservatism before and after the MCCG is included in Bursa Malaysia listing rules. The magnitude of coefficient on NEG*RET in the post-MCCG period is larger than that in the pre-MCCG period, indicating that Malaysian firms in general exhibit greater accounting conservatism in the post-MCCG period. This is supported further by a positive and statistically significant coefficient on POST*NEG*RET in Panel C. These results support our first hypothesis that the inclusion of MCGG in Bursa Malaysia listing requirements in 2001 improves accounting conservatism.

Table 5 presents the results from regression model (1) for the PC firms' and non-PC firms' subsamples, as well as regression model (3) with dummy variables PC and POST. All regression models were run with control variables SIZE, LEV, and PB. The results in Table 5 Panel A show that non-PC firms exhibit accounting conservatism before and after the MCCG (the coefficients on NEG*RET are positive and statistically significant at the $1 \%$ significance level). The magnitude of the coefficient on NEG*RET is larger in the post-MCCG period, indicating that non-PC firms exhibit improved accounting conservatism in the post-MCCG period (the coefficients on NEG*RET are 10.49 and 18.38 in the preand post-MCCG period, respectively). 
TABLE 4

ACCOUNTING CONSERVATISM AND MCCG

\begin{tabular}{|c|c|c|c|c|c|c|c|c|c|}
\hline \multirow[b]{2}{*}{ Variables } & \multicolumn{3}{|c|}{ Panel A - Pre-MCCG } & \multicolumn{3}{|c|}{ Panel B - Post-MCCG } & \multicolumn{3}{|c|}{$\begin{array}{c}\text { Panel C - Full Sample } \\
\text { Period } \\
\end{array}$} \\
\hline & Est. & $\begin{array}{c}\text { t- } \\
\text { value }\end{array}$ & $\begin{array}{c}\text { p- } \\
\text { value }\end{array}$ & Est. & $\begin{array}{c}\text { t- } \\
\text { value }\end{array}$ & $\begin{array}{c}\text { p- } \\
\text { value }\end{array}$ & Est. & $\begin{array}{c}\mathrm{t}- \\
\text { value }\end{array}$ & $\begin{array}{c}\mathrm{p}- \\
\text { value }\end{array}$ \\
\hline Intercept & 7.05 & 8.62 & $<.0001$ & 7.60 & 9.50 & $<.0001$ & 6.05 & 7.77 & $<.0001$ \\
\hline \multicolumn{10}{|c|}{ Experimental variables: } \\
\hline$N E G$ & -0.02 & -0.01 & 0.99 & -1.70 & -1.16 & 0.25 & 0.91 & 0.69 & 0.49 \\
\hline$R E T$ & 0.71 & 0.96 & 0.33 & 4.20 & 3.65 & 0.00 & 0.80 & 1.11 & 0.27 \\
\hline$N E G * R E T$ & 9.32 & 3.87 & 0.00 & 19.89 & 4.92 & $<.0001$ & 9.32 & 3.84 & 0.00 \\
\hline POST & & & & & & & 2.02 & 2.08 & 0.04 \\
\hline$P O S T * N E G$ & & & & & & & -2.71 & -1.64 & 0.10 \\
\hline$P O S T$ *RET & & & & & & & 1.93 & 1.76 & 0.08 \\
\hline$P O S T * N E G^{*} R E T$ & & & & & & & 8.00 & 2.18 & 0.03 \\
\hline \multicolumn{10}{|l|}{ Control variables: } \\
\hline SIZE & 0.00 & -0.06 & 0.95 & 0.02 & 0.25 & 0.80 & 0.01 & 0.29 & 0.77 \\
\hline$S I Z E^{*} N E G$ & -0.02 & -0.52 & 0.61 & 0.04 & 0.29 & 0.77 & -0.02 & -0.47 & 0.64 \\
\hline$S I Z E^{*} R E T$ & 0.00 & 0.05 & 0.96 & 0.06 & 0.32 & 0.75 & 0.02 & 0.30 & 0.76 \\
\hline$S I Z E^{*} N E G^{*} R E T$ & -0.04 & -0.61 & 0.54 & -0.64 & -1.44 & 0.15 & -0.03 & -0.49 & 0.63 \\
\hline$L E V$ & -0.70 & -2.62 & 0.01 & -0.10 & -1.65 & 0.10 & 0.01 & 0.21 & 0.84 \\
\hline$L E V^{*} N E G$ & 0.84 & 2.50 & 0.01 & 0.48 & 2.33 & 0.02 & 0.07 & 0.67 & 0.51 \\
\hline$L E V^{*} R E T$ & 0.02 & 0.11 & 0.92 & 0.78 & 3.61 & 0.00 & 0.07 & 0.51 & 0.61 \\
\hline$L E V^{*} N E G^{*} R E T$ & 0.42 & 0.67 & 0.50 & -0.01 & -0.01 & 0.99 & 0.19 & 0.61 & 0.54 \\
\hline$P B$ & 0.28 & 0.17 & 0.86 & 9.45 & 2.15 & 0.03 & -0.61 & -0.40 & 0.69 \\
\hline$P B * N E G$ & -0.53 & -0.32 & 0.75 & -18.42 & -3.00 & 0.00 & 0.25 & 0.16 & 0.88 \\
\hline$P B * R E T$ & -3.33 & -1.06 & 0.29 & -61.80 & -4.47 & $<.0001$ & -6.10 & -1.90 & 0.06 \\
\hline$P B * N E G * R E T$ & 2.94 & 0.89 & 0.37 & 39.29 & 2.22 & 0.03 & 5.41 & 1.60 & 0.11 \\
\hline Adj. R-square & $1.97 \%$ & & & $6.80 \%$ & & & $3.98 \%$ & & \\
\hline $\begin{array}{l}\text { Firm-year } \\
\text { observations: }\end{array}$ & 2,478 & & & 3,172 & & & 5,650 & & \\
\hline \multicolumn{10}{|c|}{$\begin{array}{l}\text { RET is holding-period stock return including dividends over the fiscal year; NEG is a dummy variable for negative } \\
\text { return, equal to } 1 \text { if RET }<0 \text { and } 0 \text { otherwise; POST is the period dummy variable, } 1 \text { for period after MCCG's } \\
\text { integration into Bursa Malaysia, and } 0 \text { otherwise; SIZE is the log of market value at the beginning of the year; LEV } \\
\text { is the firm's leverage as measured by total liabilities divided by total assets; and PB is Price-to-Book ratio at the } \\
\text { beginning of the year. The coefficients on the control variables (SIZE, LEV, and PB) are not tabulated due to space } \\
\text { constraint. }\end{array}$} \\
\hline
\end{tabular}


Table 5 Panel B shows the regression results for the PC firm sample before and after the MCCG. The results indicate that in the pre-MCCG period, PC firms do not exhibit accounting conservatism (the coefficient on NEG*RET is not statistically significant). In the post-MCCG period, however, PC firms exhibit accounting conservatism (the coefficient on NEG*RET is positive and statistically significant at the 5\% significance level). These results indicate that the MCCG improves the accounting conservatism of PC firms in Malaysia.

A formal test of the statistical significance of differences in accounting conservatism among the firm groups ( $\mathrm{PC}$ and non-PC), before and after the MCCG, is provided by a pooled cross-sectional regression model as shown in Table 5 Panel C. The coefficient on POST*NEG*RET is positive and significant, providing evidence of improved accounting conservatism for non-PC firms group in the post-MCCG period. Furthermore, the coefficient on POST*PC*NEG*RET is positive and statistically significant, indicating that PC firms show improved accounting conservatism in the post-MCCG period, and PC firms exhibit more timely loss recognition (accounting conservatism) compared to non-PC firms in the postMCCG period. These results provides empirical evidence supporting our second hypothesis, that there is a difference in the impact of MCCG on accounting conservatism of $\mathrm{PC}$ and non-PC firms. More specifically, MCCG results in a greater improvement in the accounting conservatism of PC firms, compared to that of non-PC firms.

TABLE 5

ACCOUNTING CONSERVATISM, MCCG AND POLITICAL CONNECTIONS

\begin{tabular}{|c|c|c|c|c|c|c|c|c|c|c|c|}
\hline \multirow{4}{*}{$\begin{array}{l}\text { Variables } \\
\text { Intercept }\end{array}$} & \multicolumn{6}{|c|}{ Panel A: Non-PC Firms } & \multicolumn{5}{|c|}{ Panel B: PC Firms } \\
\hline & \multicolumn{3}{|c|}{ Pre-MCCG } & \multicolumn{3}{|c|}{ Post-MCCG } & \multicolumn{2}{|c|}{ Pre-MCCG } & \multicolumn{3}{|c|}{ Post-MCCG } \\
\hline & \multirow{2}{*}{$\begin{array}{r}\text { Est. } \\
6.97\end{array}$} & \multicolumn{2}{|c|}{ t-value } & \multirow{2}{*}{$\begin{array}{c}\text { Est. } \\
6.34\end{array}$} & \multicolumn{2}{|c|}{ t-value } & \multirow{2}{*}{$\begin{array}{l}\text { Est. } \\
10.26\end{array}$} & t-value & \multirow{2}{*}{$\begin{array}{l}\text { Est. } \\
26.30\end{array}$} & \multicolumn{2}{|c|}{ t-value } \\
\hline & & 7.23 & $\begin{array}{l}* * \\
*\end{array}$ & & 8.24 & $* * *$ & & $3.30 \quad * * *$ & & 4.18 & $* * *$ \\
\hline$N E G$ & 0.17 & 0.11 & & -0.62 & -0.44 & & -1.67 & -0.31 & -15.67 & -1.68 & $*$ \\
\hline$R E T$ & 0.43 & 0.44 & & 5.34 & 4.82 & $* * *$ & 2.68 & 1.05 & -17.38 & -2.08 & $* *$ \\
\hline$N E G^{*} R E T$ & 10.49 & 3.90 & $\begin{array}{l}* * \\
*\end{array}$ & 18.38 & 4.65 & $* * *$ & 4.32 & 0.38 & 58.85 & 2.47 & $* *$ \\
\hline Adj. R-square & $2.76 \%$ & & & $6.76 \%$ & & & $0.00 \%$ & & $6.20 \%$ & & \\
\hline $\begin{array}{l}\text { Firm-year } \\
\text { observations }\end{array}$ & 2,129 & & & 2,929 & & & 349 & & 243 & & \\
\hline
\end{tabular}




\begin{tabular}{|c|c|c|c|c|c|c|c|c|c|}
\hline \multirow{4}{*}{$\begin{array}{l}\text { Variables } \\
\text { Intercept }\end{array}$} & \multicolumn{9}{|c|}{ Panel C: All Firms } \\
\hline & \multicolumn{3}{|c|}{ Pre-MCCG } & \multicolumn{3}{|c|}{ Post-MCCG } & \multicolumn{3}{|c|}{ Full Sample Period } \\
\hline & \multirow{2}{*}{$\begin{array}{l}\text { Est. } \\
6.892\end{array}$} & \multicolumn{2}{|c|}{ t-value } & \multirow{2}{*}{$\begin{array}{l}\text { Est. } \\
6.301\end{array}$} & \multicolumn{2}{|c|}{ t-value } & \multirow{2}{*}{$\begin{array}{l}\text { Est. } \\
5.920\end{array}$} & \multicolumn{2}{|c|}{ t-value } \\
\hline & & 8.21 & $* * *$ & & 7.75 & $* * *$ & & 7.24 & $* * *$ \\
\hline$N E G$ & -0.106 & -0.08 & & -0.608 & -0.41 & & 0.832 & 0.60 & \\
\hline$R E T$ & 0.506 & 0.67 & & 5.144 & 4.44 & $* * *$ & 0.641 & 0.85 & \\
\hline$N E G^{*} R E T$ & 9.318 & 3.71 & $* * *$ & 18.281 & 4.48 & $* * *$ & 9.321 & 3.65 & $* * *$ \\
\hline$P C$ & 1.791 & 0.91 & & 19.926 & 7.42 & $* * *$ & 1.372 & 0.65 & \\
\hline$P C^{*} N E G$ & -0.184 & -0.06 & & -16.468 & -3.74 & $* * *$ & 0.103 & 0.03 & \\
\hline$P C^{*} R E T$ & 1.856 & 1.08 & & -19.626 & -4.65 & $* * *$ & 1.014 & 0.56 & \\
\hline$P C * N E G * R E T$ & -0.786 & -0.13 & & 29.689 & 2.67 & $* * *$ & -0.048 & -0.01 & \\
\hline$P O S T$ & & & & & & & 0.873 & 0.86 & \\
\hline$P O S T^{*} N E G$ & & & & & & & -1.642 & -0.94 & \\
\hline POST*RET & & & & & & & 2.898 & 2.53 & $* *$ \\
\hline$P O S T^{*} N E G^{*} R E T$ & & & & & & & 6.396 & 1.66 & $*$ \\
\hline$P O S T^{*} P C$ & & & & & & & 18.193 & 5.49 & $* * *$ \\
\hline$P O S T^{*} P C^{*} N E G$ & & & & & & & -15.714 & -2.90 & $* * *$ \\
\hline$P O S T^{*} P C * R E T$ & & & & & & & -17.870 & -4.12 & $* * *$ \\
\hline$P O S T^{*} P C^{*} N E G^{*} R E T$ & & & & & & & 27.096 & 2.18 & $* *$ \\
\hline Adj. R-square & $2.03 \%$ & & & $7.89 \%$ & & & $4.92 \%$ & & \\
\hline Firm-year observations & 2,478 & & & 3,172 & & & 5,650 & & \\
\hline \multicolumn{10}{|c|}{$\begin{array}{l}\text { RET is holding-period stock return including dividends over the fiscal year; NEG is a dummy variable for } \\
\text { negative return, equal to } 1 \text { if RET }<0 \text { and } 0 \text { otherwise; PC is dummy variable for political connections, } 1 \text { for PC } \\
\text { firm, and } 0 \text { otherwise; POST is the period dummy variable, } 1 \text { for period after MCCG's integration into Bursa } \\
\text { Malaysia listing rules, and } 0 \text { otherwise. The coefficients on the control variables (SIZE, LEV, and PB) are not } \\
\text { tabulated due to space constraint. } \\
* * *, * *, * \text { indicate statistical significance at the } 1 \%, 5 \% \text {, and } 10 \% \text { level, respectively. }\end{array}$} \\
\hline
\end{tabular}

Table 6 shows the results from the accrual-based accounting conservatism measure. The coefficient on $\mathrm{PC} * \mathrm{DCFO} * \mathrm{CFO}$ is negative and statistically significant at $1 \%$ significance level, indicating that $\mathrm{PC}$ firms exhibit less conservative accounting compared to their non-PC firms counterparts during the preMCCG period. The coefficient on POST*DFCO*CFO is not statistically significant, indicating that there is no evidence of improvement in the accounting conservatism of non-PC firms the post-MCCG. The coefficient on $\mathrm{PC} * \mathrm{POST} * \mathrm{DCFO} * \mathrm{CFO}$ is positive and statistically significant at $10 \%$ significance level, indicating that $\mathrm{PC}$ firms exhibit improved timely loss recognition in the post-MCCG period, and further, they exhibit greater accounting conservatism compared to non-PC firms in the post-MCCG period. In general, these results are consistent with our main tests using Basu (1997) accounting conservatism measure. 
TABLE 6

ACCRUAL-BASED ACCOUNTING CONSERVATISM MEASURE

\begin{tabular}{lccc}
\hline Variables & Estimates & t-value & p-value \\
\hline Intercept & 0.087 & 26.65 & $<.0001$ \\
$D C F O$ & -0.065 & -10.90 & $<.0001$ \\
$C F O$ & -0.923 & -52.79 & $<.0001$ \\
$D C F O^{*} C F O$ & -0.031 & -0.97 & 0.3313 \\
$P C$ & -0.073 & -7.03 & $<.0001$ \\
$P C^{*} D C F O$ & 0.086 & 5.17 & $<.0001$ \\
$P C^{*} C F O$ & 0.776 & 9.54 & $<.0001$ \\
$P C^{*} D C F O^{*} C F O$ & -0.707 & -6.74 & $<.0001$ \\
$P O S T$ & -0.060 & -13.69 & $<.0001$ \\
$P O S T^{*} D C F O$ & 0.089 & 11.71 & $<.0001$ \\
$P O S T^{*} C F O$ & 0.465 & 16.87 & $<.0001$ \\
$P O S T^{*} D C F O * C F O$ & -0.003 & -0.08 & 0.9361 \\
$P C^{*} P O S T$ & 0.037 & 2.47 & 0.0135 \\
$P C^{*} P O S T^{*} D C F O$ & -0.072 & -2.60 & 0.0092 \\
$P C^{*} P O S T^{*} C F O$ & -0.412 & -3.99 & $<.0001$ \\
$P C^{*} P O S T^{*} D C F O * C F O$ & 0.329 & 1.66 & 0.0973 \\
\hline Adj. R-square & $96.91 \%$ & & \\
\hline Firm-year observations: & 5,581 & & \\
\hline$A C C$ is accruals deflated by total assets at the beginning of the fiscal year; $C F O$ is cash flow \\
from operation deflated by the beginning total assets; $D C F O$ is a dummy variable for negative \\
cash flows, equal to 1 if $C F O<0$ and 0 otherwise; $P O S T$ is the period dummy variable, 1 for \\
period after MCCG is integrated into Bursa Malaysia in 2001, and 0 otherwise. $P C$ is a \\
dummy variable for political connection, equal to 1 if the firm has political connection and 0 \\
otherwise. The coefficients on the control variables $(S I Z E, L E V$, and $P B)$ are not tabulated due \\
to space constraint. & & & \\
\hline
\end{tabular}

We also ran the regressions without observations from 2001, as this year can be viewed as a transition year. We did not find significant changes in the results even after removing observations from 2001.

\section{CONCLUSIONS}

The purpose of this study is to explore the relationships between accounting conservatism, the incorporation of MCCG in Bursa Malaysia listing requirements in 2001, and firms' political connections in Malaysia. We find empirical evidence that MCCG improved accounting conservatism. This result is consistent with prior studies that find evidence that MCCG improved corporate governance practice in Malaysia (Wahab et al., 2007), and improved corporate governance code is positively associated with improved accounting conservatism (Marzuki et al., 2016). Further, we find evidence that even though non-PC firms exhibit accounting conservatism both before and after the MCCG, their accounting conservatism is greater after the MCCG. PC firms, on the other hand, do not exhibit accounting conservatism before the MCCG, and their accounting conservatism significantly improved after the MCCG. Our result also indicates that PC firms exhibit more timely loss recognition (greater accounting conservatism) than non-PC firms after the MCCG. 
Our results suggest that the integration of MCCG in Bursa Malaysia listing rules is effective in improving the accounting conservatism of firms in Malaysia. This is consistent with the notion that improved corporate governance standards increases the demand for higher reporting quality. Interestingly, firms with political connections responded to the MCCG more strongly than non-PC firms, from showing lack of accounting conservatism in the period before the MCCG to a stronger accounting conservatism compared to non-PC firms after the MCCG.

Overall, our results support the view that before the mandatory implementation of MCCG in Bursa Malaysia listing rules in 2001, PC firms have lower or no incentive to produce high quality financial reports, including timely loss recognition, for several possible reasons. First, PC firms have a lesser need to respond to market demand for timely loss recognition, because information asymmetric often is resolved through private communications rather than through public disclosures. Second, timely recognition of economic losses that generally is crucial in debt contract is not as important for PC firms due to their relatively easier access to financing and lower cost of debt. Finally, prior research suggests that timely loss recognition increases with legal enforcement (Lang, Raedy, \& Yetman, 2003; Raonic et al., 2004). Prior to Malaysia corporate governance reform in 2001, PC firms may receive less stringent regulatory oversight and negative consequences for poor quality reporting from the government and market regulators, creating less incentive for timely loss recognition. The Malaysian corporate governance reform that includes the integration of MCCG in the Bursa Malaysia listing rules, and the creation of the MSWG, created pressure for the PC firms to produce better financial reporting quality, including improved accounting conservatism. PC firms may face more public scrutiny after the corporate governance reform, especially with the establishment of the MSWG. Because non-PC firms always were expected to produce high-quality financial reports to obtain financing, the corporate governance reform will have a lesser impact on their reporting behavior compared to PC firms.

There are several limitations of this study. First, our study uses a long time-series data from 19882006. During this period, significant events that occurred in Malaysia may have affected financial reporting quality and firms' market performance (e.g., Asian financial crisis in 1997/1998, Malaysian capital controls in 1998, etc.). Second, our initial PC firm data is based on firms identified by Faccio (2006). Although this proxy is considered objective, and has been used by many studies, we recognize that it is not a perfect proxy. It is possible that firms that perhaps should have been identified as politically connected remain unrecognized, and identified connected firms may have weaker or stronger connections during our study period. To deal with this concern, we reconciled the PC firms list from Faccio (2006) with the PC firms list developed by Fung et al. (2015). This reconciliation alleviates some of the concerns about the existence of the identified connections throughout the period of the study. In addition, many studies that use Faccio's (2006) list argue that the stability of the political power in Malaysia reduces the concern of whether political ties continue to exist over a long period of time. Finally, it should be noted that this study does not examine corporate governance variables. Instead, this paper investigates whether accounting conservatism in Malaysia changed after the integration of MCCG in Bursa Malaysia listing rules. Future research may investigate the impact of various corporate governance variables (such as the extent of managerial ownerships, state ownership, block holders, the board of directors' composition, etc.) on accounting conservatism, before and after MCCG was incorporated in Bursa Malaysia listing rules. 


\section{REFERENCES}

Ahmed, A. S. \& Duellman, S. (2007). Accounting conservatism and board of director characteristics: An empirical analysis. Journal of Accounting and Economics, 43, 411-437.

Ahmed, K. \& Henry, D. (2012). Accounting conservatism and voluntary corporate governance mechanisms by Australian firms. Accounting and Finance, 52, 631-662.

Ball, R., Robin, A., \& Wu, J. S. (2003). Incentives versus standards: Properties of accounting income in four East Asian countries. Journal of Accounting and Economics, 36(1-3), 235-270.

Ball, R. \& Shivakumar, L. (2005). Earnings quality in UK private firms: Comparative loss recognition timeliness. Journal of Accounting and Economics, 39, 83-128.

Basu, S. (1997). The conservatism principle and the asymmetric timeliness of earnings. Journal of Accounting and Economics, 24(1), 3-37.

Beekes, W., Pope, P. \& Young, S. (2004). The links between earnings timeliness, earnings conservatism and board composition: Evidence from the UK. Corporate Governance, 12(1), 47-59.

Bliss, M. and Gul, F. (2012a). Political connections and cost of debt: Some Malaysian evidence. Journal of Banking and Finance, 36(5), 1520-1527.

Bliss, M., \& Gul, F. (2012b). Political connections and leverage: Some Malaysian evidence. Journal of Banking \& Finance, 36(8), 2344-2350.

Bliss, M., Gul, F., \& Majid, A. (2011). Do political connections affect the role of independent audit committees and CEO duality? Some evidence from Malaysian audit pricing. Journal of Contemporary Accounting and Economics, 7, 82-98.

Bushman, R. M. \& Piotroski, J. D. (2006). Financial reporting incentives for conservative accounting: The influence of legal and political institutions. Journal of Accounting and Economics, 42(1), 107-148.

Bushman, R. M., Piotroski, J. D., \& Smith, A. J. (2004). What determines corporate transparency? Journal of Accounting Research, 42(2), 207-252.

Chaney, P. K., Faccio, M., \& Parsley, D. C. (2011). The quality of accounting information in politically connected firms. Journal of Accounting and Economics, 51(1), 58-76.

Christie, A. A. (1987). On cross sectional analysis in accounting research. Journal of Accounting and Economics, 9, 231-258.

Claessens, S., Djankov, S., Fan, J. P. H., \& Lang, L. H. P. (1999). Expropriation of minority shareholders: Evidence from East Asia. Policy Research Working Paper Series. Washington, DC: The World Bank.

Faccio, M. (2006). Politically connected firms. The American Economic Review, 96(1), 369-386.

Faccio, M. (2007). The characteristics of politically connected firms. Working paper. West Lafayette, IN: Purdue University.

Finance Committee on Corporate Governance (1999). The KLSE/PriceWaterhouse joint survey of the corporate governance practices in public-listed companies - executive summary. Report on Corporate Governance. Kuala Lumpur.

Finance Committee on Corporate Governance (2000). Malaysian Code on Corporate Governance. Kuala Lumpur: Securities Commission.

Fraser, D. R., Zhang, H., \& Derashid, C. (2006). Capital structure and political patronage: The case of Malaysia. Journal of Banking and Finance, 30, 1291-1308.

Fung, S. Y. K., Gul, F. A., \& Radhakrishnan, S. (2015). Corporate political connections and the 2008 Malaysian election. Accounting, Organizations and Society, 43, 67-86.

Garcia Lara, J. M., Osma, B. G., \& Penalva, F. (2009). Accounting conservatism and corporate governance. Review of Accounting Studies, 14, 161-201.

Gomez, E. T. \& Jomo. K. S. (1997). Malaysia's political economy. Cambridge, England: Cambridge University Press.

Guay, W. \& Verrecchia, R. (2006). Discussion of an economic framework for conservative accounting and Bushman and Piotroski.Journal of Accounting and Economics, 42, 149-165. 
Gul, F. A. (2006). Auditors' response to political connections and cronyism in Malaysia. Journal of Accounting Research, 44(5), 931-963.

Johnson, S. \& Mitton, T. (2003). Cronyism and capital controls: Evidence from Malaysia. Journal of Financial Economics, 67(2), 351-382.

Lang, M., Raedy, J., \& Yetman, M. (2003). How representative are firms that cross-listed in the United States? An analysis of accounting quality. Journal of Accounting Research, 41(2), 363-386.

Leong, H. K. (2005). Reforming Corporate Governance in South East Asia: Economics, Politics, and Regulations. Singapore: Institute of Southeast Asian Studies.

Lim, M., How, J., \& Verhoeven, P. (2014). Corporate ownership, corporate governance reform and timeliness of earnings: Malaysian evidence. Journal of Contemporary Accounting and Economics, 10, 32-45.

Marzuki, M. M. \& Wahab, E. A. A. (2016). Institutional factors and conditional conservatism in Malaysia: Does international financial reporting standard convergence matter? Journal of Contemporary Accounting \& Economics, 12, 191-209.

Marzuki, M. M., Wahab, E. A. A., \& Haron, H. (2016). Corporate governance and earnings conservatism in Malaysia. Accounting Research Journal, 29(4), 391-412.

Mohammed, N. F., Ahmed, K., \& Ji, X. (2017). Accounting conservatism, corporate governance and political connections. Asian Review of Accounting, 25(2), 288-318.

Mitton, T. (2002). A cross-firm analysis of the impact of corporate governance on the East Asian Financial Crisis. Journal of Financial Economics, 642, 215-241.

Rajan, R. G. \& Zingales, L. (1998). Which capitalism? Lessons from the East Asian crisis. Journal of Applied Corporate Finance, 11(3), 40-48.

Raonic, I., McLeay, S., \& Asimakopoulos, I. (2004). The timeliness of income recognition by European companies: An analysis of institutional and market complexity. Journal of Business, Finance, and Accounting, 31(1-2), 115-148.

Shleifer, A., \&Vishny, R. W. (1997). A survey of corporate governance. Journal of Finance, 52, 737783.

Sterling, R. R. (1970). The theory of measurement of enterprise income. Lawrence, KS: University of Kansas Press.

Wahab, E. A. A., How, J. C. Y., \& Verhoeven, P. (2007). The impact of the Malaysian Code of Corporate Governance: Compliance, institutional investors and stock performance. Journal of Contemporary Accounting \& Economics, 3(2), 106-129.

Watts, R. L. (2003a). Conservatism in accounting Part I: Explanations and implications. Accounting Horizons, 17, 207-221.

Watts, R. L. (2003b). Conservatism in accounting, Part II: Evidence and research opportunities. Accounting Horizons, 17, 287-301. 